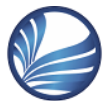

ELK

Asia Pacific Journals

www.elkjournals.com

\title{
DYNAMICS BETWEEN VIETNAMESE REAL CONSUMPTION AND ECONOMIC GROWTH
}

\author{
Chu V. Nguyen \\ PhD., Associate Professor of Economics, Chairman: \\ FAEIS Department, \\ College of Business, \\ University of Houston-Downtown, \\ 320 North Main St., Suite 410-D, Houston, \\ Texas 77002 \\ Email: nguyenchu@uhd.edu
}

\begin{abstract}
This article uses recent developments in econometric techniques to examine the consumption-led growth hypothesis for Vietnam from 1990-2012. The Granger-causality tests were based on two testing approaches: the vector error correction modeling approach outlined in Toda and Philips, and the augmented level VAR modeling with integrated and cointegrated processes (of arbitrary orders) separately introduced by Toda and Yamamoto (1993) and Dolado and Lütkepohl (1996). Empirical results reveal the mutual exogeneity between the Vietnamese real consumption and GDP growth. This exogeneity poses great challenges for the Vietnamese policymakers who must rebalance their transitional economy. This change, necessitated by recent crises in the international economic landscape, necessitates a shift in the Vietnamese economy from an export-led growth economy to a more inclusive, services-oriented, and consumer-based.
\end{abstract}

Key Words: Washington consensus development hypothesis; Vietnam; Johansen cointegration test; TYDL augmented VAR procedure; ELG hypothesis; Granger causality; development strategy.

\section{Introduction}

The growth and progress of every economy, developed, or otherwise, are inevitably marked by periods of instability. As a result, virtually all economies worldwide have, at some point, experienced both internal and external shocks and disturbances. Internally, unstable investment and consumption patterns combined with improper implementation of public policies, have proven to be key factors in the destabilization of many economies. External factors such as wars, revolutions, population growth rates and migration, technological transfer and changes as well as the openness 


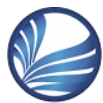

ELK

Asia Pacific Journals

www.elkjournals.com

of the economy can also create instabilities in international economies.

Cyclical fluctuations in economic activities have resulted in both periodic increase in unemployment and inflation rates and in disequilibria in the external sector (Gbosi, 2001). In his sentential General Theory (1936), Keynes articulated that the task of restoring these macroeconomic variables to their long-term trends cannot be permitted to simply fall upon the market forces of supply and demand. Countercyclical fiscal, monetary, and international trade policies present major economic stabilization instruments, as they involve measures meant to regulate and control volume, cost, and availability as well as measures intended to direct an economy's funds toward activities that will support specified macroeconomic policy objectives and counteract undesirable economic trends.

Monetary policy and fiscal policies are two approaches by which governments attempt to manage national economies. Fiscal policies revolve around government's expenditure and taxation powers to influence the economy, while monetary policy uses either interest rates or the money supply to ensure stable economic growth. Although monetary and fiscal policies have differing effects, both strive to ensure economic stability.

In the macroeconomic management of market economies, the Keynesian fiscal policy has been playing a crucial role in the late 1930s. Beginning from 1960s, international economic changes have persistently resulted in huge government budget deficits in world economies. As articulated by Mishkin (1995), partly because of concern over budget shortfalls and partly because of doubt that the political system can utilize the fiscal policy instrument in a timely manner to achieve the desirable stabilization outcome, the stabilization of inflation as well as output has been largely left to monetary policy. 


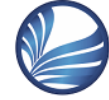

ELK

Asia Pacific Journals

www.elkjournals.com

In the age of globalization, transitional economies such as that of Vietnam and the People's Republic of China, have relied on exports as the engine driving GDP growths. While an export-led based development strategy has often acted as a catalyst in economic development in these transitional economies, this type of policy has also subjected many countries to severe blows to national economic growth, as a result of international financial crises that disseminate dangerous contagions. The recent US subprime mortgage crisis and the European sovereign debt phenomenon, for example, produced ripple effects that extended to multiple developing nations. In fact, the US subprime mortgage crisis has caused the exports of Vietnam and China to decrease drastically. These reductions in exports along with their attendant consequences forced policymakers in these countries to rebalance their economic development strategies by promoting domestic consumptions as the primary economic growth mechanism.
Econometrically, Awokuse (2003) articulated that a long-run behavioral relationship between two macroeconomic variables such as export-GDP growth and consumption-GDP growth requires econometric procedures appropriate for long-tern equilibria. Clearly, the short-run dynamic and causal behavioral relationship between consumption and economic growth represents information important to the design and implementation of national countercyclical economic policies. This short-run dynamic causality also requires an appropriate empirical procedure.

This study aims to estimate empirically the short- and long-run Granger causalities between Vietnamese consumption and the country's GDP in order to investigate the effectiveness of rebalancing the Vietnamese transitional economy toward promoting increased domestic consumption as a replacement for a reduction in exports. The present research builds on Awokuse's (2005-a) methodology to investigate the Granger causality between 


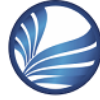

ELK

Asia Pacific Journals

www.elkjournals.com

Vietnamese domestic consumption and output growth by applying the following recent developments in statistical time series techniques: (i) the vector error correction modeling (VECM) approach outlined in Toda and Phillips (1993); and (ii) the augmented level VAR modeling including co-integrated and integrated processes (of arbitrary orders), introduced by Toda and Yamamoto (1995) and Dolado and Lütkepohl (1996) in separate studies identified as, TYDL. As pointed out by Awokuse (2005-a), the latter methodological approach is particularly useful because it eliminates the need for potentially biased cointegration and units roots pre-tests, which are imperative for other formulations.

It is noteworthy that Granger causality is not a conventional causal relationship. Rather, as pointed out by Granger (1969), the definition of Granger causality is based entirely on the predictability of some series - w, for example. If some other series $\mathrm{y}$, contains past information that facilitates prediction of $\mathrm{w}$; and if this information is not contained in any other series utilized in the predictor, then $\mathrm{y}$ is said to Granger cause w. Additionally, if $\mathrm{x}_{2}$ Ganger causes $\mathrm{x}_{1}$, but $\mathrm{x}_{1}$ does not Granger causes $\mathrm{x}_{2}$, then, there is a unidirectional Granger causality from $\mathrm{x}_{2}$ to $\mathrm{x}_{1}$ or $\mathrm{x}_{2}$ is weakly exogenous from $\mathrm{x}_{1}$. Otherwise, if $\mathrm{x}_{2}$ Ganger causes $\mathrm{x}_{1}$ and $\mathrm{x}_{1}$ also Granger causes $\mathrm{x}_{2}$; then, their Granger causality is bidirectional.

The remaining portion of study is organized as follows. The following section briefly reviews the literature and some background of development theories; the next section summarizes the prominent features of the Vietnamese economy; the section that follows discusses the data, methodology, and descriptive statistics; the subsequent section summarizes the empirical outcomes; and the final section presents concluding remarks.

\section{Review of Literature and Historical Background}




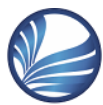

ELK

Asia Pacific Journals

www.elkjournals.com

\subsection{Historical Background}

The global citizenry, still reeling from the devastating destruction caused by World War II, sent delegates, in 1944, to the Bretton Woods Conference, which became better known as the United NationsMonetary and Financial Conference. In the twentieth century, many theoretical development strategies were formulated and implemented in an effort to assuage human suffering around the globe by rebuilding war-torn economies, e.g.: the Marshall Plan for Europe, the reconstruction of Japan, the economic development plans at the UN General Assembly and Economic and Social Council. Today, theoretical development strategies can be broadly classified into two categories: inward-looking and outwardlooking strategies. These strategies are also referred to as import-subsidized and exportled development strategies. The theoretical foundation for the inward-looking development strategy is based on the Keynesian economic theory (Singer 1998), which advocates the subsidized import of capital and the development of labor as means to industrialize the economy. This import-subsidized development strategy is now better known as the Prebisch-Singer Hypothesis, named for Sir Hans W. Singer and Raúl Prebisch, strong proponents of this theory. The Prebisch-Singer Hypothesis formed the foundation of many Latin America development policies put into practice over the course of the 1950s.

The neoclassical economic theory is the theoretical foundation of the export-led development strategy, which is the brainchild of the Bretton Woods Institutions. This development strategy is better known as the Washington Consensus development strategy. The export-led development strategy advocates that all economies should concentrate on developing the export sector as a key component of their development processes. This strategy has led to exponential growth in the volume of international trade, increased capital mobility, and closer connections, through the last three decades, among the 


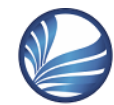

ELK

Asia Pacific Journals

www.elkjournals.com

international economies. While this development strategy may be the catalyst for economic development around the world, it also creates an environment conducive to international financial crises that could result from dangerous contagions, such as that demonstrated by the recent US subprime mortgage crisis and the most recent European sovereign debt crisis.

\subsection{Review of Literature}

The demand-side macroeconomic school of thought has long postulated a causal relationship between consumption and GDP growth, which is the theoretical foundation for the countercyclical macroeconomic policy framework. Additionally, the consumption theory in macroeconomics clearly postulates that GDP, and hence consumer's incomes, stand as the main determinant of the level of aggregate consumption. The aforementioned theories collectively posit a bidirectional causality, at least in the Granger sense, between aggregate consumption and GDP.
While the bidirectional causality between aggregate consumption and GDP has been well articulated theoretically, the empirical investigation of this theoretically articulated bidirectional causality remains very limited. Guisan (2001) provided an extensive review of cointegration and causality and between GDP and private consumption in twentyfive OECD countries over the period of 1960-1997. The author suggested using a country's own GDP (excluding GDPs of other countries in the group) as the sole explanatory variable in the investigating process. Guisan (2004) evaluated the power of Granger Causality, Modified Granger Causality, Engle-Granger Cointegration, Two Stage Least Squares, and Hausman tests in detecting the causal relationship between real consumption and GDP in Mexico and the United States. He found that while private consumption is highly dependent on GDP, the degree of dependence lowers down when the variables are reversed. 


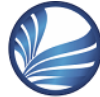

ELK

Asia Pacific Journals

www.elkjournals.com

More recently, Gomez-Zaldivar and Ventosa-Santaularia (2009) further investigated the causality between consumption and GDP in Mexico and the United States. The authors found no evidence of either causality or cointegration between Mexican series for consumption and GDP; but, in the case of the US series, the authors found that the two are cointegrated, with a unidirectional causality from consumption to GDP. Mishra (2011) investigated the dynamic relationship between real consumption expenditure and economic growth in India over the period of 1950-2008 and found a long-term unidirectional causality from real consumption expenditure to economic growth. However, the author reported that there is no short-term Granger causality between these two macroeconomic variables.

\section{The Vietnamese Economy}

The performance of the Vietnamese 'Socialist-oriented market economy with the
State's intervention' since 1986 has been a splendid but unfinished story, which may become a splendid story with the creative destruction, destroying all the earlier creativity at the end. Therefore, it is possible that the incomplete part of the story may prove that the splendid story may end up not much splendid at all!

The transition of the Vietnamese economy begin in 1986 with an extensive reform program, known as "Doi Moi" (renovation) after the country had undergone extreme hardship and economic crisis. Economically, the heart of the reform program was a compromise of the Vietnamdefined 'Socialist-oriented market economy with the State's intervention.' This slogan simply means a legitimate capitalistic economic model, with the political power uniquely gripped by the Communist Party.

As to the splendid part of the story, the GDP of the Vietnamese Socialistoriented market economy with the State's intervention grew at a rapid rate of $6.9 \%$ 


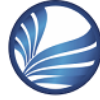

ELK

Asia Pacific Journals

www.elkjournals.com

annually over the period 1996-2000 and accelerated to 7.5 percent annually during 2001-2005. Over this rapid growth, it consumed huge capital and physical assets; for example, official development assistance funding of $\$ 15$ billion occurred during 20012005 alone. In addition, Vietnam attracted an increasing stock of foreign direct investments, amounting to more than 14,000 projects with nearly $\$ 210$ billion committed by the end of 2012, Vuong and Napier (2013). The equity market is the supposed poster child of the Vietnamese financial sector, which has benefitted greatly from market liberalization. The positive sentiment, stemming from the favorable economic conditions, helped send Vietnam's stock market index, from its inaugural value of 100 on July 28, 2000 to its peak of 1,170.00 in March 2007, in spite of the considerable international, political, and social turmoil of the 2000s.

To describe what has transpired in the Vietnamese economy, as cited by Currie
(2008), Klaus Rohland, the World Bank's Vietnam country director from 2002 to 2007 stated that "over the past 15 years, there has been no other country in the world that has developed to this extent so quickly." This characterization is in diametric contrast with Vietnam in the1990s which was mostly mentioned in policy circles for having some of the most inappropriate reforms among the transitional economies, Kim (2008).

As to the creative destruction of the Vietnamese Socialist-oriented market economy with the State's intervention, Djankov et al. (2005) articulated that the flood of foreign aid results in rent seeking activities where the involvement of politicians in power may lead to misallocation of resources as well as exclusion of other groups from the political process. Perhaps the windfall of capital inflows does the same as well. As to the magnitude, Djankov et al. (2005) statistically demonstrated that "aid is a bigger curse than oil" meaning that aid is a 


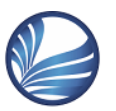

ELK

Asia Pacific Journals

www.elkjournals.com

more dangerous Dutch disease than oil for Vietnam.

The incomplete part may eventually prove that the splendid story may end up not much splendid at all! To this end, Vuong and Napier (2013) articulated that over time, Vietnam's emerging economy has appeared inefficient, wasting physical and capital resources as measured by the "Investmentto-GDP" ratio. For example, this ratio has risen over three critical phases: 34.9 percent from 1996 to $2000 ; 39.1$ percent in period 2001-2005 and 43.5 percent over 2006-2010 period. The authors further argued that these increases indicated that the country needed more scarce resources to finance growth.

In addition, in the financial sector, financial institutions infused huge credit amounts to the economy, evidenced by the statistics that for the 2000-2010 decade the credit supply grew at an astonishing rate of 1,370.00 percent, while GDP doubled in the same decade. Elsewhere, scarce physical assets such as land, housing and mines, have likewise been used inefficiently by "special interest groups", including the so called "crony capitalists" who despite having access to uncommon information yield mediocre performance. The state-owned enterprises, for instance, officially borrowed over $\$ 60$ billion but created a total market equity value of only $\$ 33$ billion (Vuong, 2012).

Macroeconomic theory clearly articulated that reliance on credit to finance growth has generated high inflation. The Vietnamese Socialist-oriented market economy with the State's intervention is no exception. The aforementioned credit growth resulted in high inflation in the decade, peaking at $23 \%$ in 2008 . Inflationary pressure forced the monetary authority to tighten the credit market pushing interest rates for credit to as high as 25.00 percent. Consequently, high cost of credit resulted in insolvencies or quietly closed operations of over 100,000 enterprises from early 2011 to 


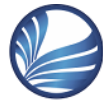

ELK

Asia Pacific Journals

www.elkjournals.com

the end of 2012. These failed businesses are mostly private because they did not receive governmental subsidies or borrowing privileges. These insolvent or closed businesses accounted for between 15 percent and 25 percent of the Vietnamese enterprise population, (Vuong, 2012).

More unsettling, the aforementioned misuse of resources and cronyism have enriched some but impoverished the majority of the populace, which resulted in the elite group being very rich and controlling the vast income and wealth in the economy, with the majority of the population hardly making the ends meet, and very few in between. Over time, the influent group with almost unlimited purchasing power would develop a taste for luxurious commodities which are usual imports. Their demands for these commodities are usually very low elastic. This dichotomy in the economy may uncouple the long held shot- and long-run macroeconomic relationship between consumption and GDP. These relationships are the critical theoretical foundation for the countercyclical fiscal policy in modern macroeconomics.

After decades of impressive growth, the Vietnamese per capita GDP has hovered at a lower threshold of the mid-income economy. The Vietnamese economy has entered the current period of more moderate expansion. Clearly, the slowdown in Vietnamese growth is in many ways related to the unfavorable international economic conditions bestowed by the recent financial crises that affected the entire world. The GDPs of advanced economies remain well below their potential levels, contributing to lower demand for Vietnamese exports - a key source of growth for Vietnam perusing export led growth development strategy.

The blend of higher investments, slower growth, and rapid expansion of credit points to diminishing returns and growth of the economy as achieved by absorbing 


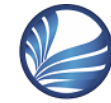

ELK

Asia Pacific Journals

www.elkjournals.com

surplus labor into the factories from countryside and sole reliance on accumulation of physical capital. Vietnamese export-led growth model may be running out of steam. Continuing to push the limits of this growth model may lead the Vietnamese convergence process in becoming a middle income economy to a stand-still and widen the vulnerabilities. As aforementioned, the US subprime mortgage and the European sovereign debt crises have forced the Vietnamese authority to reenergize their reform efforts to accelerate the transition to an economy that is consumer based, services orientated and is more inclusive. If the macroeconomic long held relationship between consumption and GDP growth is uncoupled, the rebalancing of the economy becomes very elusive.

\section{The Data, Methodology, and Descriptive Statistics}

The great challenge in empirical studies of developing and emerging economies is the availability of data. This study utilizes the data available in respect of real GDP and real consumption (COM) in vietnam. The data set covers the period from 1990 to 2012, and include all available data. All relevant data was procured from the IMF databases and are expressed in natural logarithms.

In order to apply the augmented $\mathrm{VAR}[\mathrm{k}+\mathrm{d}(\max )]$ model developed by TYDL, one must build the original lag order as suggested in the VAR model, $k$, and the maximum order of integration for the variable under consideration. To the maximum order of integration for the time series in question, $d(\max )$, two standard unit root tests were performed: the PP- PhilipsPerron test (1988) and ADF- augmented Dickey-Fuller test (1979). For both tests, the null hypothesis is that a unit root exists in the autoregressive representation of the series. The augmented Dickey-Fuller and Phillips-Perron unit root test results are reported in Table 1. An analysis of the test outcomes points to the presence of unit roots in level. Both series are found to be 


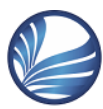

ELK

Asia Pacific Journals

www.elkjournals.com

stationary after first differencing. These findings indicate that the series under consideration are non-stationary and integrated of order I(1); hence, this study uses $d(\max )=1$ in further analysis.

Table 1: ADF and PP test results, Vietnamese Annual Data 1990 to 2012

\begin{tabular}{lcccc}
\hline & \multicolumn{2}{c}{ Augmented Dickey- Fuller } & \multicolumn{2}{c}{ Phillips- Perron } \\
Series & Level & First Differencing & Level & First Differencing \\
\hline GDP & -1.5144 & $-4.2800^{*}$ & -1.5144 & $-4.2800^{*}$ \\
IP & -0.0295 & $-4.4210^{*}$ & -1.6570 & $-4.2800^{*}$ \\
\hline
\end{tabular}

Note: “*” denotes rejections of the hypothesis at the 1 percent level.

Schwarz information criterion (SC). The

Moreover, the lag order of the original VAR can be determined by using several lag order selection criteria such as the final prediction error (FPE), the sequential modified LR test statistic (LR), Hannan-Quinn information criterion (HQ), Akaike information criterion (AIC) and the results of the lag selection procedure are reported in Table 2. The stistics- LR, FPE, AIC, SC, and HQ, all suggest using 1 as the lag length. Subsequent analysis therefore proceeds with the use of VAR with lag length equal to 1 .

Table 2: Maximum Lag length: Vietnamese Annual Data 1990 to 2012

\begin{tabular}{cccllll}
\hline Lag & Log L & LR & FPE & AIC & SC & HQ \\
\hline 0 & 61.52144 & NA & $8.92 \mathrm{e}-06$ & -5.952144 & -5.852571 & -5.932707 \\
1 & 134.0536 & $123.3047^{*}$ & $9.46 \mathrm{e}-09^{*}$ & $-12.80536^{*}$ & $-12.50664^{*}$ & $-12.74705^{*}$ \\
2 & 136.7543 & 4.051046 & $1.10 \mathrm{e}-08$ & -12.67543 & -12.17757 & -12.57824 \\
3 & 137.1592 & 0.526324 & $1.63 \mathrm{e}-08$ & -12.31592 & -11.61891 & -12.17985 \\
\hline
\end{tabular}

Notes: * indicates lag order selected by the criterion

LR: sequential modified LR test statistic (each test at $5 \%$ level)

FPE: Final prediction error

AIC: Akaike information criterion

$S C$ : Schwarz information criterion

HQ: Hannan-Quinn information criterion 


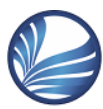

ELK

Asia Pacific Journals

www.elkjournals.com

Additionally, Engle and Granger (1987) argued that if two series are integrated of order one, I(1), there is need to test among the variables, the probability of a co-integrating long-run relationship. Only a brief overview of the methodology for cointegration and error correction is provided here since it is widely available in literature (Engle and Granger 1987; Johansen and Juselius 1990; Banerjee et al. 1993). The multivariate co-integration model by Johansen and Juselius' (1990), is based on the following representation of error correction:

$$
\Delta X_{t}=\mu+\sum_{i=1}^{p-1} \Gamma_{i} \Delta X_{t-1}+\Pi X_{t-1}+\varepsilon_{t}
$$

where $X_{t}$ is an $\left(\begin{array}{lll}n & x & 1\end{array}\right)$ column vector of $\mathrm{p}$ variables, $\mu$ is an ( $n \times 1)$ vector of constant terms, $\Delta$ is a difference operator, $\Gamma$ and $\Pi$ are coefficient matrices, $\mathrm{k}$ represents the lag length, and $\varepsilon_{t} \sim N(0, \Sigma)$. The coefficient matrix, $\Pi$, also called the impact matrix; contains information regarding the long-run relationships. Johansen and Juselius' (1990) methodology demands the calculation of the VAR equation (1), subsequently, likelihood ratios (LR) are estimated using the residuals. The LR test statistics are instrumental in the calculation of the unique cointegrating vectors of $X_{t}$. the maximal eigenvalue test and the trace test can be used to evaluate the number of co-integrating vectors. The analysis is reported in table 3 :

Table 3: Johansen Cointegration Test Results, Vietnamese Annual Data 1990 to 2012

\begin{tabular}{lcccc}
\hline & \multicolumn{2}{c}{ Trace Statistics } & \multicolumn{2}{c}{ Max-Eigen Statistics } \\
\cline { 3 - 5 } Number of cointegrating vectors & Statistics & $\mathbf{C ~ ( 5 \% )}$ & Statistics & $\mathbf{C ~ ( 5 \% )}$ \\
\hline $\boldsymbol{r} \leq \mathbf{0}$ & $26.5969^{*}$ & 20.2618 & $21.7877^{*}$ & 15.8921 \\
$\boldsymbol{r} \leq \mathbf{1}$ & 4.8092 & 9.1646 & 4.8092 & 9.1646 \\
\hline
\end{tabular}

Note: ** denotes rejection of the hypothesis at the 5 percent level.

As shown in Table 3, results for cointegration tests suggest the existence of, 


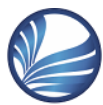

ELK

Asia Pacific Journals

www.elkjournals.com

at most, one cointegrating vector. This implies the presence of one independent common stochastic trends in this system of two variables.

Moreover, the augmented VAR procedure, proposed by Toda and Yamamoto (1995) and Dolado and Lutkepohl (1996), supports the VECM technique as it allows for causal inference on the basis of an augmented level VAR with integrated and cointegrated processes. For evaluating the dynamic causal relationship between economic growth and real consumption, the following VAR in level specification was adopted:

$$
X_{t}=\mu+\sum_{i=1}^{p-1} \Gamma_{i} X_{t-k}+\varsigma_{t}
$$

where $X_{t}$ is an $\left(\begin{array}{lll}n & x & 1\end{array}\right)$ column vector of $\mathrm{p}$ variables, $\mu$ is an (nx l) vector of constant terms, $\Gamma$ denotes coefficient matrices, $k$ represents the lag length, and $\varsigma_{t}$ is i.i.d. and $p$ indicates the dimensional Gaussian error with mean zero and variance matrix $\Lambda$.

As pointed out by Awokuse (2005a), the TYDL procedure uses a modified Wald test for the restriction on the parameters of the $\operatorname{VAR}(k)$ model. This test has an asymptotic chi-squared distribution with $k$ degrees of freedom in the limit when a $\operatorname{VAR}[k+d(\max )]$ is estimated, where $\mathrm{d}(\max )$ is the maximal order of integration for the series in the system. Awokuse (2005b) further articulates the attraction of the TYDL approach in that prior knowledge about cointegration and testing for unit root are not necessary once the extra lags, i.e., $\mathrm{d}(\max )$ lags, are included, Given that $\operatorname{VAR}(k)$ is selected, and the order of integration $\mathrm{d}(\max )$ is determined, a level VAR can then be estimated with a total of $\mathrm{p}=[\mathrm{k}+\mathrm{d}(\max )]$ lags. Finally, the standard Wald tests are applied to the first $k$ VAR coefficient matrix (but not all lagged coefficients) to make Granger causal inference. 


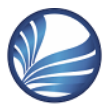

ELK

Asia Pacific Journals

www.elkjournals.com

\section{Empirical Results}

Based on the appropriate lag length $k$ $=1$ and the $d(\max )=1$, above determined, the Granger causality test results using both the VECM and the augmented level VAR specifications are reported in Table 4. Fstatistics and $p$-values (in parentheses) for Granger causality tests from the VECM specification are presented in Table 4(a).

Table 4: Granger Causality Test Results, Vietnamese Annual Data 1990 to 2012

\begin{tabular}{lcc}
\hline (a) Results based on error correction model (VECM) & \\
\hline Dep. & Short-run lagged differences $(F$-statistics) & \\
\cline { 2 - 3 } Variables & $\Delta$ GDP & $0.0935(0.9108)$ \\
\hline$\Delta$ GDP & ----- & ---- \\
$\Delta$ COM & $0.0231(0.9772)$ & \\
\hline (b) Results based on an augmented VAR model (TYDL procedure) & \\
\hline Dep. & (Modified Wald-statistics) & COM \\
Variables & GDP & $0.1863(0.6660)$ \\
\hline GDP & ---- & ---- \\
COM & $0.0999(0.7519)$ &
\end{tabular}

Notes: The $[k+d(\max )]$ th order level VAR was estimated with $d(\max )=1$ for the order of integration equals 1 .

Lag length selection of $k=1$ was based on LR, FPE, AIC, SC, and HQ.

Reported estimates are asymptotic Wald statistics. Values in parentheses are p-values.

An analysis of the empirical results indicates that growth in Vietnamese GDP is exogenous from changes in aggregate consumption, since the null hypothesis that the changes in real consumption 'Grangercauses' growth in real GDP is rejected at the 5 percent significance level $(\mathrm{p}=0.9108)$. Additionally, an inspection of the real consumption equation (in row 2) indicates that the null hypothesis that the real GDP 'Granger-causes' real consumption could be rejected at any level of significance. These empirical findings reveal the exogeneity between changes in Vietnamese consumption and GDP. Similar to conclusions from panel (a) of Table 4, causality results from the TYDL testing 


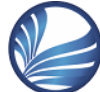

ELK

Asia Pacific Journals

www.elkjournals.com

approach [see panel (b) of Table 4] also indicate the exogeneity between consumption and GDP in the Vietnamese Socialist-oriented market economy with the State's intervention over the 1990-2012 period.

\section{Concluding Remarks}

This study adopts the recently developed estimation techniques to analyze the relationship between Vietnamese consumption and GDP growth in order to investigate whether the stimulus of the intermediate target variable of macroeconomic policy, aggregate consumption, leads to a desirable impact on the ultimate target variable of GDP. More specifically, to test the Granger causality, the VECM and the augmented level VAR model with integrated and cointegrated processes (of arbitrary orders) developed by Toda and Yamamoto (1995) and Dolado and Lütkepohl (1996) were used. Granger causality tests based on both alternative models, using annual data collected from the period of 1990-2012, indicates an exogeneity between real consumption and real GDP growth.

Since the beginning, under the context of 'Socialist-oriented market economy with the State's intervention', Vietnam has followed the export-led development strategy. The essence of this Washington conscious development strategy relies on physical capital accumulation and absorption of surplus labor from the countryside into factories to produce exporting commodities. To describe the Vietnamese economy since 1986, Klaus Rohland, the World Bank's Vietnam country director from 2002 to 2007 stated that "over the past 15 years, there has been no other country in the world that has developed to this extent so quickly." This characterization is in diametric contrast with Vietnam in the1990s which was mostly mentioned in policy circles for having some of the most 


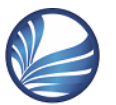

ELK

Asia Pacific Journals

www.elkjournals.com

inappropriate reforms among the transitional economies, Kim (2008).

Since 2008, the Vietnamese transitional economy has entered the period of a blend of higher investments, slower growth, and rapid expansion of credit which points to diminishing returns and limits growth of the economy as achieved by absorbing surplus labor into the factories from countryside and sole reliance on accumulation of physical capital; the Vietnamese export-led growth model may be running out of steam. Clearly, continuing to push the limits of this growth model may lead the Vietnamese convergence process in becoming a middle income economy to a stand-still and widen the vulnerabilities. To counter the adverse effects of the US subprime mortgage and the European sovereign debt crises, the Vietnamese authority has tried to re-energize their reform efforts to accelerate the transition to a more inclusive, services-oriented, consumer-based economy.
The finding of exogeneity suggests that an increase in Vietnamese consumption would not lead to GDP growth, as theorized by macroeconomic theory. It would not be an easy endeavor to ensure a favorable rebalance, and would demand a comprehensive package of reforms that would make the economy better reliant on total factor productivity rather than on accumulation of factors. In the corrupt business environment in the economy, this reform package must include greater contestability of markets, financial and service sector reforms, and especially mechanisms to eliminate corruption and cronyism in the economy. Ultimately, the pace at which Vietnam implements this reform package will determine Vietnam's medium-term growth prospects and success in transitioning from a low to a middleincome country. Unfortunately, given the international competition in the age of globalization, the window for designing and 


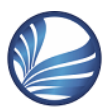

ELK

Asia Pacific Journals

www.elkjournals.com

implementing such a required reform program is quickly closing.

\section{References}

[1] Awokuse, TO 2005, Exports, Economic Growth and Causality in Korea. Applied Economics Letters, 12: 693-696. http://dx.doi.org/10.1080/135048505001 88265

[2] 2003, Is the Export-Led

Growth Hypothesis Valid for Canada? Canadian Journal of Economics, 36: 126-36. http://dx.doi.org/10.1111/15405982.00006

[3] Banerjee, A., Dolado, JJ, Galbraith, JW and Hendry, DF 1993, Co-integration, Error Correction, and the Econometric Analysis of Non-Stationary Data. Oxford University Press, Oxford. http://dx.doi.org/10.1093/0198288107.0 01.0001

[4] Djankov, S, Montalvo, J G and ReynalQuerol, M 2005, The curse of aid. Economics Working Papers, No. 870,
Department of Economics and Business, Universitat Pompeu Fabra.

[5] Dickey, DA and Fuller, WA 1979, Distribution of the Estimators for Autoregressive Time Series with a Unit Root. Journal of the American Statistical Association, 74: 427-31. http://dx.doi.org/10.2307/2286348

[6] Dolado, JJ and Lütkepohl, H 1996, Making Wald Tests Work for Cointegrated VAR Systems. Econometric Reviews, 15: 369-86. http://dx.doi.org/10.1080/074749396088 00362

[7] Engle, RF and Granger, CWJ 1987, Cointegration and Error Correction: Representation, Estimation, and Testing. Econometrica, $\quad 55: \quad 251-76$. http://dx.doi.org/10.2307/1913236

[8] Gbosi, AN 2001, Contemporary Macroeconomic Problems and Stabilization Policies in Nigeria, Antovic Ventures, Port Harcourt

[9] Gomez-Zaldivar, $\mathrm{M}$ and VentosaSantaularia, D 2009, The Bilateral 


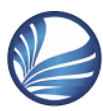

ELK

Asia Pacific Journals

www.elkjournals.com

Relationship between Consumption and GDP in Mexico and the US: A Comment. Applied Econometrics and International Development. 9(1): 77-90.

[10] Granger, CWJ1969, Investigating

Causal Relations by Econometric Models and Cross-Spectral Methods. Econometrica, Vol. (37(3), pp. 424-438. http://dx.doi.org/10.2307/1912791

[11] Guisan, MC 2001, Causality and Cointegration between Consumption and GDP in 25 OECD Countries: Limitation of the Cointegration Approach. Applied Econometrics and International Development. 1(1): 39-61. 2004, A Comparison of Causality Tests Applied to the Bilateral Relationship between Consumption and GDP in the USA and Mexico. International Journal of Applied Econometrics and Quantitative Studies. 1: 115-130.

[13] Johansen, S and Juselius, K 1990 Maximum Likelihood Estimation and Inference on Cointegration- with
Applications to the Demand for Money. Oxford Bulletin of Economics and Statistics, 52: 169-210. http://dx.doi.org/10.1111/j.1468-

0084.1990.mp52002003.x

[14] Keynes, J M 1936, The General

Theory of Employment, interest and

Money. New York.

[15] Kim, AM 2008, Learning to Be Capitalists in Vietnam's Transition Economy, Oxford University Press, New-York, USA. http://dx.doi.org/10.1093/acprof:oso/978 0195369397.001 .0001

[16] Mishkin, FS 1995, Symposium on the Monetary Transmission Mechanism. Journal of Economic Perspectives, 9(4). pp.

http://dx.doi.org/10.1257/jep.9.4.3

[17] Mishra, PK 2011, Dynamics of the Relationship between Real Consumption Expenditure and Economic Growth in India. Indian Journal of Economics \& Business, 10(4): 553-563. 


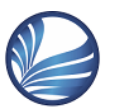

ELK

Asia Pacific Journals

www.elkjournals.com

[18] Perron, P 1997, Further Evidence on

Breaking Trend Functions in

Macroeconomic Variables. Journal of

Econometrics, 80. pp. 355-385.

http://dx.doi.org/10.1016/S0304-

4076(97)00049-3

[19] Singer, HW 1998, Growth,

Development and Trade. Edward Elgar Publishing Company, UK.

[20] Toda, H.Y and Phillips, PCB 1993, Vector Autoregressions and Causality. Econometrica, 61: 1367-93. http://dx.doi.org/10.2307/2951647

[21] Toda, HY and Yamamoto, T 1995, Statistical Inference in Vector
Autoregressions with Possibly Integrated Processes. Journal of Econometrics, 66: 225-50. http://dx.doi.org/10.1016/03044076(94)01616-8

[22] Vuong, QH 2012, Vietnam's economic challenges. Stratfor Global Intelligence. Retrieved February 20, 2013, from http://www.stratfor.com/othervoices/vietnams-economic-challenges.

[23] Vuong, QH and Napier, NK 2013, Resource Curse or Destructive Creation in Transition Turmoil (May 2, 2013). China-USA Business Review, Vol. 12, No. 5, pp. 486-493, 2013. Available at SSRN: http://ssrn.com/abstract=2260037 